\title{
The Effect of Intellectual Intelligence and Emotional Intelligence on Competence and Employees Performances
}

\author{
Darman Darman ${ }^{1}$ and Wahyu Maulid Adha ${ }^{2}$

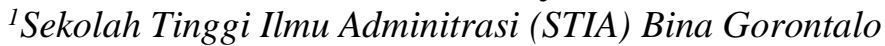 \\ ${ }^{2}$ Universitas Sulawesi Barat \\ Email Address: \\ darman@ubmg.ac.id; wahyuadha@unsulbar.ac.id
}

\begin{abstract}
This study aims to test the relationship and influence between intellectual intelligence and emotional intelligence towards competency and performance and partially test both variables. The object of this study was a civil servant at the Gorontalo Regency Regional Secretariat Office with a sample of 150 respondents by spreading questioner online. This study also uses structural equation technique with data analysis using SEMPLS. The results showed that intellectual intelligence variables positively and significantly influence employees' competence and performance. On the other hand, emotional intelligence does not have a significant effect on employee performance. This research can reference relevant agencies in looking at the relationship between intellectual intelligence and emotional intelligence to employees' competence and performance to take the right policies. This research in the design is static. The model that we developed based on empirical studies and testing is limited to establishing simple relationships related to intellectual intelligence and emotional intelligence variables that can affect employees' competence and performance.
\end{abstract}

Keywords: Intellectual intelligence; emotional intelligence; competence; employee performance.

\begin{abstract}
Abstrak: Penelitian ini bertujuan untuk menguji hubungan dan pengaruh antara kecerdasan intelektual dan kecerdasan emosional terhadap kompetensi dan kinerja serta menguji kedua variabel tersebut secara parsial. Objek penelitian ini adalah Pegawai Negeri Sipil pada Kantor Sekretariat Daerah Kabupaten Gorontalo dengan jumlah sampel 150 responden dengan cara menyebarkan kuisioner secara online. Penelitian ini juga menggunakan teknik persamaan struktural dengan analisis datanya menggunakan SEM-PLS. Hasil penelitian menunjukkan bahwa variabel kecerdasan intelektual berpengaruh positif dan signifikan terhadap kompetensi dan kinerja karyawan. Sedangkan kecerdasan emosional tidak berpengaruh signifikan terhadap kinerja karyawan. Penelitian ini dapat menjadi acuan instansi terkait dalam melihat hubungan antara kecerdasan intelektual dan kecerdasan emosional dengan kompetensi dan kinerja pegawai untuk mengambil kebijakan yang tepat. Penelitian yang di desain ini bersifat statis. Model yang kami kembangkan berdasarkan studi dan pengujian empiris terbatas pada membangun hubungan sederhana terkait dengan variabel kecerdasan intelektual dan kecerdasan emosional yang dapat mempengaruhi kompetensi dan kinerja karyawan.
\end{abstract}

Kata Kunci: Kecerdasan intelektual; kecerdasan emosional; kompetensi; kinerja karyawan. 


\section{INTRODUCTION}

The ability to carry out various mental activity is intellectual intelligence. People with a high intellectual understanding will use logic to think, so they will understand, of course, what a person does and the consequences of this action (Princess, 2020). This intelligence offers the capacity to collect, hold or manage information in facts, to reason, to plan and to think rationally about the job (Andreana and Putri, 2020). In line with this, the emotional intelligence concerns, in addition to the role of their intellectual intelligence, their ability to detect and manage their intelligence and instructions (Pangestu and Efendi, 2019). This emotional intelligence is intended to acknowledge personal emotions, so that they know their strengths and their faults, their ability to manage these emotional experiences, their ability to motivate and to encourage people to move on to themselves (Rusnali, 2020). Subsequently, this intelligence will help to manage emotions in the face of demand (Wiguna and Yadnyana 2019) as well as environmental pressures to fully utilize cognitive skill, to motivate and to interact with others (Putri, 2020). Ethical behaviour, because emotional intelligence is included in the inherent part of decision making. emotional intelligence (Wiguna and Yadnyana, 2019). A person with higher emotional intelligence will be better qualified in emotional thinking. Through emotional intelligence, a person is more likely to orient himself to ethical behavior (Andreana and Putri, 2020). It helps to recognize the ethical and ethical behavior of a person (Singh and Dangmei, 2016; Nguyen and Nguyen, 2020). This emotional intelligence serves to activate your intellectual intelligence effectively (Dewi and Wirakusuma, 2018).

Intellectual intelligence and emotional intelligence are indivisible personal configurations; therefore both components of intelligence are complementary in understanding, forming and developing behaviour (Wiguna and Yadnyana, 2019). In addition, these two things may shape their skills so that anyone with great intellectual and emotional intelligence can achieve maximum results (Sierra et al., 2013). Previous research has shown that intellectual intelligence and emotional intelligence can influence the individual's competence to produce success and studies (Wiguna and Yadnyana, 2019), where the level of competence of a person can be measured through awareness and management of emotional and related cognitive intelligence. The research implies the spiritual quotient variable as one of the inseparable variables between intellectual intelligence and emotional intelligence as one that can affect the level of performance of employees, not even just this, but also further research (Andreana and Putri, 2020). (Apriliani and Rahadi, 2020). The results also showed a significant influence of emotional intelligence and intellectual intelligence variables.

Subsequently, we see that public officials, especially those of the Inspectorate of Gorontalo Province, are based on the phenomenon mentioned by researchers. Researchers see that some employees have not solved the work or problems that exist by managing their emotional intelligence factors. Preliminary remarks that we made also found certain reports of their inadequacy, especially if they have a work deadline. This obviously affects your skills and your own performance (Juniari et al., 2015).

In either research, the researchers are examining the implications of competence and employee performance through the use of intellectual intelligence and emotional intelligence factors. Because these factors are an important problem for finding solutions to continuously improve performance. The aim of this study is to demonstrate the degree of 
awareness and the ability of the intellectual and emotional intelligence to influence their competence. This research is to provide theoretical insights on the impact of intellectual intelligence and emotional intelligence upon performance to agencies and competency theories. This research is intended to be a reference point for further research and can contribute to improving the performance of employees.

\section{THEORITICAL REVIEW}

Intellectual Intelligence, Competence and Performance. Intellectual intelligence seems to be activities, according to (Robbins, 2007), necessary for different thinking activities, problem solving and information in reality deducing and managing. (Mulyadi, 2014) pointed out that the profession is a community working environment which requires competence and authority. Intellectual intelligence can measure the capacity of village government officials (Rusnali, 2020). A high Intelligence worker is expected to work better than a lower IQ worker. A person with a high quality of life is easier to absorb the knowledge to increase his ability to identify and solve work-related problems. If the village government organizer has high intelligence, the knowledge he has acquired can be understood and applied. (Pangestu and Efendi 2019) said the performance of a worker with high intelligence still plays an important part in enhancing the performance of the employee.

Said by (Pangestu and Efendi, 2019), intellectual intelligence expertise controls conduct patterns in order to make them more effective and effective. This means that the higher the intelligence of a person, the more ethically people comport. To deduce intellectual intelligence, who realizes what is emerging, and mastery will respond quickly to situations and conditions. Intelligence can measure speed, measure, hold and remember the previously stored objective information. The ability of logical thinking to find objective facts and predict risk can be highlighted by intellectual intelligence.

\section{H1: Intellectual Intelligence has a significant influence on competence.}

H3: Intellectual Intelligence has a significant influence on Performance.

Emotional Intelligence, Competence, and Performance. In emotional intelligence, there are many differences of opinion. In psychology, relatively new is this field which is still in search of a more stable form. It is understood as the abilities of recognizing one's own emotions, of controlling emotions and taking appropriate measures, of recognizing one's own emotions, of acting and interacting with others. (Goleman, 2002) mentioned in addition to intellectual intelligence (Intelligence Quotient), There are other intelligences, emotional intelligence, that help a person succeed (Emotional Intelligence). In actuality, emotional intelligence performs a more successful role than intellectual intelligence.

In recent years, emotional intelligence has received considerable emphasis in social literature. It explains the importance of life satisfaction, personal accomplishment and success in life (Wiguna and Yadnyana, 2019). Moreover, emotional intelligence is the skill of one person to push himself, to survive failure, to control emotions and to control mental state according to (Pangestu, 2019). So it could be concluded that emotional intelligence has the capacity of a person to receive, evaluate, control and manage emotions and self.

According to (Goleman et al., 2006), emotional intelligence has several influencing factors : 1). Family environment, and 2). Self-confidence, 2), Self-management, 3), Social 
consciousness, 4) Motivation, 5). Relationship management. Predictor of emotional intelligence. According to (Pangestu and Defendi, 2019), social competency, motivation, empathy, self-control and self-recognition indicators are indicators of emotional intelligence. Emotional intelligence is cognition in the positive use of emotions based on desire and in the control of emotions. (Patton, 1998) prefers to use emotions effectively, so that productive relations can be built in order to achieve work success. Intellectual factors are not only seen as performance but as well as emotional factors. A person with good emotional control will also be able to perform well. Studies by (Yenti and Machasin, 2014) showed that the performance of R.S. Pekan Baru employees is affected by emotional intelligence.

This is as (Anthony, 2003), Three varying modalities influence employee performance: (1) Individual variables that consist of competencies and skills: mental and physical. Psychological variables consists entirely of perception, attitude, individuality, learning and motivation, are the following: age, origin, gender; (2) organizational variables, comprising resources, management, rewards and structure and the design of work; Two variables may also affect employee performance in addition to Include attitudes, characteristics, physical features, interests and motive, experience, age, gender, education and other factors and, Situation variables include work methods, conditions for workers and the development of work equipment, the spatial and physical environments (enlightenment, temperature, ventilation) and social and organizational factors including organization rules, organizational properties, types, wages and social environment.

H2: Emotional Intelligence has a significant influence on competence.

H4: Emotional Intelligence has a significant influence on performance.

Competence and Performance. Research results show that skills and employee performance have an influence. In other words, more competence will improve employee performance. Instead, the lower the skill, the lower the results. The following is according to (Prihadi, 2004) on the importance of jurisdiction: A cluster of related knowledge, skills and attitudes that influence a large part of the job (roles or responsibilities), that is related to job efficiency, can be measured against well-accepted standards and improved through training and development This is linked with the performance of employees in most positions (roles or responsibilities), is measured according to acceptable standards, and can be improvements via training and developing efforts."

Competence then refers to the knowledge, skill, ability or personality properties of a person that directly impact the job performance, in line with the fact. Competence includes aspects that affect performance of knowledge, qualifications and skills and personality characteristics. (Roe, 2001) also stipulates the definition of competence as competence or ability: The ability to execute a task, task or role properly is described as competence. Knowledge, skills, personal values and attitudes are integrated into competence. It's builds on knowledge and skills and is acquired through work experience and learning by doing". The capacities of the individual tasks and the ability to build knowledge and skills based on experience and learning can be described as the ability to perform a single task.

The ability is also the capacity of an individual to perform different activities in a job (Robbins, 2007). The capacity to be influenced by intellectual intelligence is according to (Robbins, 2007). (cognitive, social, emotional, cultural intelligence). Physical capabilities 
make it much more easier for an employed person to perform his/her duties so as to facilitate achieving the expected results when he or she has high intellectual intelligence and supported physical conditions that suit his/her work requirements. From the definition above, if employees' ability is increasing, then employees will be increasing as well.

\section{METHODS}

All officials working at the inspections in the Gorontalo Regency Regional Secretariat were included in the study. There are only 150 government employees in the province of Gorontalo who have been employed as officials for 5 years. Therefore, the census method with 150 respondents is the sampling method used in this study. In that research, we were also referring about an official who has been at the inspectorate of the province of Gorontalo for at least 5 years.

The study uses a Likert scale of five paragraphs to ask participants to show their performance response and how they acquired expertise during their work. The scales used in the study ranged from (1) to (2) to (3) to (2), (3) to (4) to (3) and (5) to Santa. The criteria for this sample are those with a work experience of at least five years. Considering that a working period of five years can prove that participants have sufficient expertise and performance knowledge. This facilitates more reliable study results for researchers. Four (4) variables, intellectual intelligence, emotional intelligence; Competence, and employee performance were also used for this report.

This indicator is measured the Smart PLS-Structural Equation Modeling or Structural Equation Modeling (SEM). This study tests the relationship of intellectual intelligence and emotional intelligence with varying competences. The study is also intended to examine indirect influences. It also estimates the total articles correlation of Alpha Cronbach (CA), and the analysis of affirmative testing factor reliability, convergent validity and discriminatory validity of each concept framework structure (Jöreskog. K, 2004). Furthermore, Hypothesis Testing is conducted based on Inner Model testing (structural model), which includes r-square output, parameter coefficient, and t-statistics. To see whether or not a hypothesis can be accepted by paying attention to the value of importance between contracts, statistics and p-values, among others. This test was carried out by the software SmartPLS (Partial Least Square) 3.0. The bootstrapping results show these values. T-statistics $>1.96$ were the thumb rules used in this study with p-value of $0.05(5 \%)$, and the coefficient of beta is positive.

\section{RESULTS}

The external model is a model that defines the relationship of latent variables and their indicators or the external model defines the way each indicator relates to the latent variable. The outer model is construed to include: convergent value, discriminating value validity, composite reliability, average versatility extracted (AVE), and alpha Cronbach. In the picture below the PLS algorithm model is shown. 


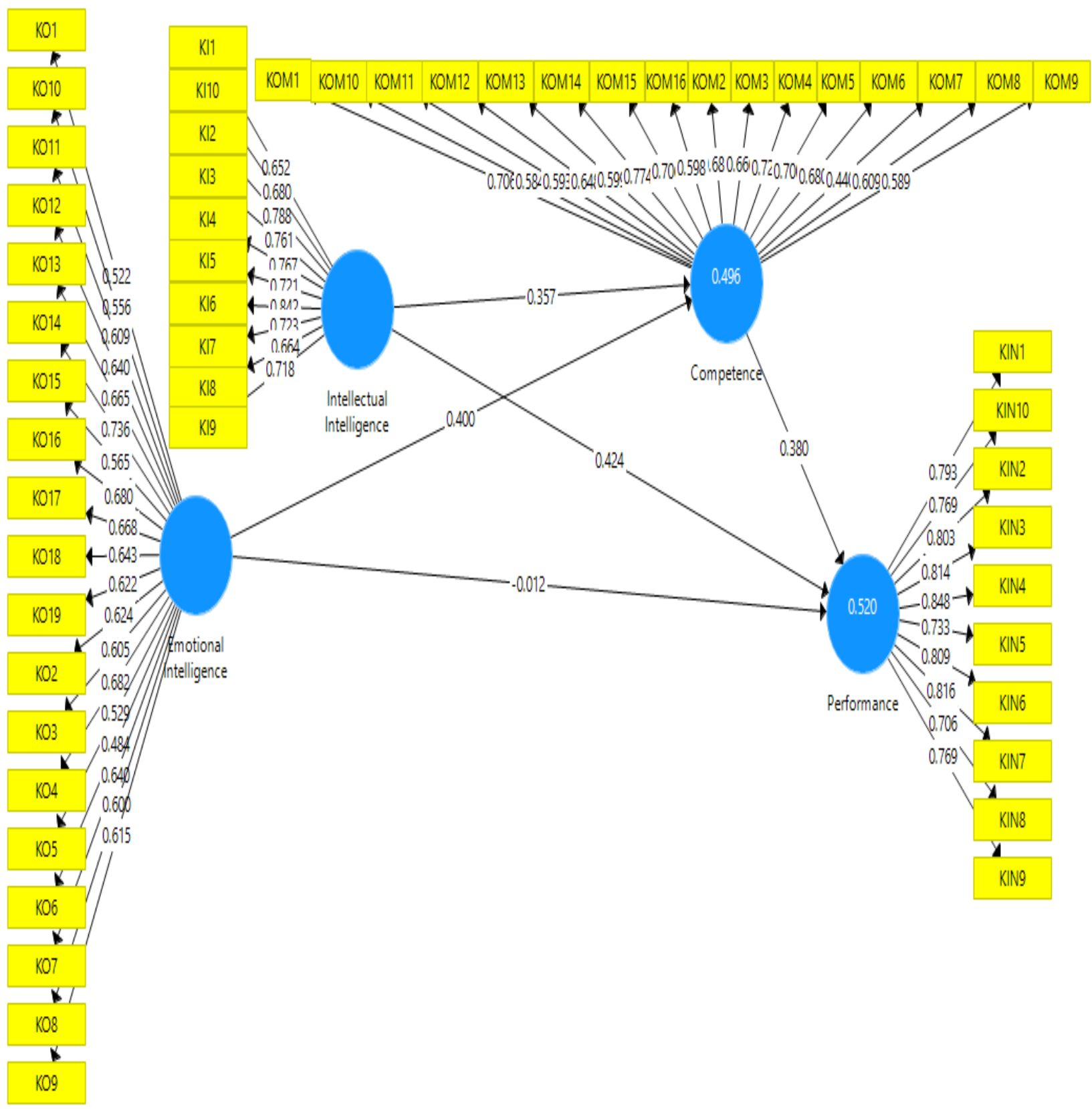

Figure 1. PLS Algorithm Model 1

The convergent value measures for each latent variable the magnitude of the loading factor. A loading factor above 0.70 is highly recommended; however, it is still possible to tolerate a loading factor above 0.60 , as long as the model is still in development. The results of the full loading indicator value are presented in the table below. 
Table 1. Outer Loadings Value

\begin{tabular}{|c|c|c|c|c|}
\hline & $\begin{array}{l}\text { Intellectual } \\
\text { Intelligence }\end{array}$ & $\begin{array}{c}\text { Emotional } \\
\text { Intelligence }\end{array}$ & Competence & $\begin{array}{c}\text { Employees } \\
\text { Performances }\end{array}$ \\
\hline KI1 & 0,652 & & & \\
\hline $\mathrm{KI} 2$ & 0,788 & & & \\
\hline KI3 & 0,761 & & & \\
\hline KI4 & 0,767 & & & \\
\hline KI5 & 0,721 & & & \\
\hline KI6 & 0,842 & & & \\
\hline KI7 & 0,723 & & & \\
\hline KI8 & 0,664 & & & \\
\hline KI9 & 0,718 & & & \\
\hline KI10 & 0,680 & & & \\
\hline KO1 & & 0,522 & & \\
\hline KO2 & & 0,624 & & \\
\hline KO3 & & 0,605 & & \\
\hline KO4 & & 0,682 & & \\
\hline KO5 & & 0,529 & & \\
\hline KO6 & & 0,484 & & \\
\hline KO7 & & 0,640 & & \\
\hline KO8 & & 0,600 & & \\
\hline KO9 & & 0,615 & & \\
\hline KO10 & & 0,556 & & \\
\hline KO11 & & 0,609 & & \\
\hline KO12 & & 0,640 & & \\
\hline KO13 & & 0,665 & & \\
\hline KO14 & & 0,736 & & \\
\hline KO15 & & 0,565 & & \\
\hline KO16 & & 0,680 & & \\
\hline KO17 & & 0,668 & & \\
\hline KO18 & & 0,643 & & \\
\hline KO19 & & 0,622 & & \\
\hline KOM1 & & & 0,706 & \\
\hline KOM2 & & & 0,685 & \\
\hline KOM3 & & & 0,666 & \\
\hline KOM4 & & & 0,722 & \\
\hline KOM5 & & & 0,700 & \\
\hline KOM6 & & & 0,680 & \\
\hline KOM7 & & & 0,440 & \\
\hline KOM8 & & & 0,609 & \\
\hline KOM9 & & & 0,589 & \\
\hline KOM10 & & & 0,584 & \\
\hline KOM11 & & & 0,593 & \\
\hline KOM12 & & & 0,648 & \\
\hline KOM13 & & & 0,599 & \\
\hline KOM14 & & & 0,774 & \\
\hline KOM15 & & & 0,706 & \\
\hline KOM16 & & & 0,598 & \\
\hline KIN1 & & & & 0,793 \\
\hline KIN2 & & & & 0,803 \\
\hline KIN3 & & & & 0,814 \\
\hline KIN4 & & & & 0,848 \\
\hline KIN5 & & & & 0,733 \\
\hline KIN6 & & & & 0,809 \\
\hline
\end{tabular}




\begin{tabular}{lc} 
KIN7 & 0,816 \\
KIN8 & 0,706 \\
KIN9 & 0,769 \\
KIN10 & 0,769 \\
\hline
\end{tabular}

Source : Output PLS (2021)

Table 1 shows that the intellectual intelligence, the value of the outer loading on the $\mathrm{KI} 1$ indicator is $0.652, \mathrm{KI} 2$ of $0.788, \mathrm{KI} 3$ of $0.761, \mathrm{KI} 4$ of $0.767, \mathrm{KI} 5$ of 0.721 , KI6 of 0.842 , KI7 of 0.723 , KI8 of 0.664 , KI9 of 0.718 and KI10 of 0.680 . Emotional intelligence contract, outer loadings on $\mathrm{KO} 1$ indicator of $0.522, \mathrm{KO} 2$ of $0.624, \mathrm{KO} 3$ of $0.605, \mathrm{KO} 4$ of $0.682, \mathrm{KO} 5$ of $0.529, \mathrm{KO} 6$ of $0.484, \mathrm{KO} 7$ of $0.640, \mathrm{KO} 8$ of $0.600, \mathrm{KO} 9$ of $0.615, \mathrm{KO} 10$ of $0.556, \mathrm{KO} 11$ of $0.609, \mathrm{KO} 12$ of $0.640, \mathrm{KO} 13$ of $0.665, \mathrm{KO} 14$ of 0.736 , KO15 of 0.565 and $\mathrm{KO} 16$ of 0.680 . Contract competence, outer loadings value on outer loadings value indicator on KOM1 indicator of $0.706, \mathrm{KOM} 2$ of 0.685 , KOM3 of $0.666, \mathrm{KOM} 4$ of $0.722, \mathrm{KOM} 5$ of 0.700 , KOM6 of 0.680 , KOM7 of 0.440 , KOM8 of 0.609 , KOM9 of 0.589 , KOM10 of 0.584 , KOM11 of 0.593 , KOM12 of 0.648 , KOM13 of 0.599 , KOM14 of 0.774 , KOM15 of 0.706 and KOM16 of 0.598 . Contract employees performances, outer loadings value on indicator KIN1 of 0.793 , KIN2 of 0.769 , KIN3 of 0.803 , KIN4 of 0.814 , KIN5 of 0.848 , KIN6 of 0.733 , KIN7 of 0.809 , KIN8 of 0.816 , KIN9 of 0.706 and KIN10 of 0.769 . From the results of the validity convergence above, there are still outer loadings values <0.6, namely KO1, KO5, KO6, KO8, KO10, KO15, KOM7, KOM9, KOM10, KOM11, KOM13, and KOM16, where the indicators are not valid then removed from the model. While indicators with outer loadings value $>0.6$ are valid, then the indicator is valid as a contract gauge. Then a second algorithm test is conducted.

From the results of the validity convergence above, there are still outer loadings values that $<0.6$, namely $\mathrm{KO} 3$ of 0.594 and $\mathrm{KO} 9$ of 0.592 , where the indicators are not valid then removed from the model. 


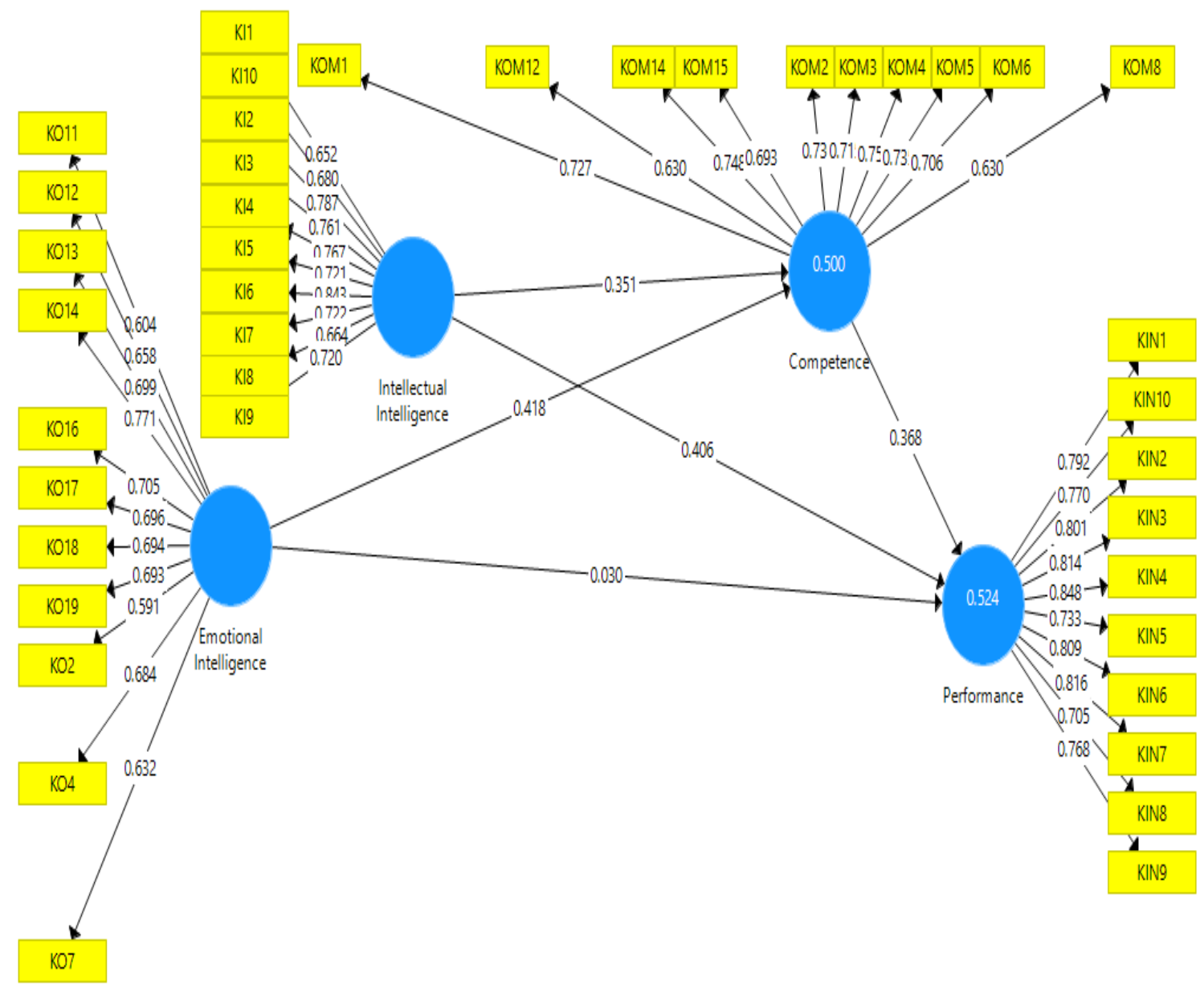

Figure 2. PLS Algorithm Model 2

From the results of the validity convergence above, there are still outer loadings values that $<0.6$, namely $\mathrm{KO} 2$ of 0.591 and $\mathrm{KO} 11$ of 0.592 , where the indicator is invalid then removed from the model. 


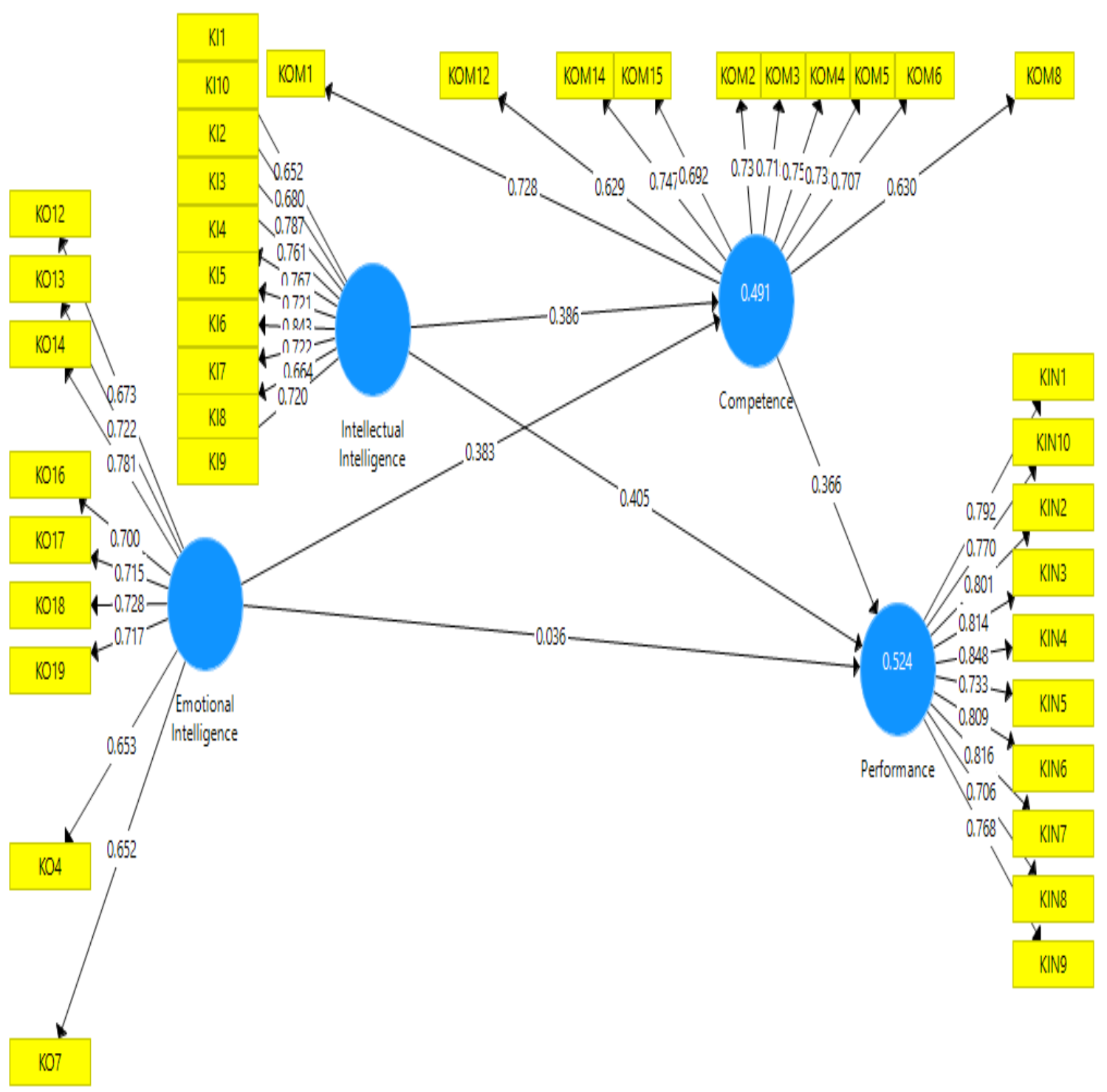

Figure 3. PLS Algorithm Model 3

The table above shows that all indicators obtain loading value with the value of the outer loading> 0.6 is valid; then, all indicators are valid as a consignment meter.

A high composite reliability value indicates the consistency of each indicator in a latent variable to measure that variable. The composite reliability value criteria $>0.7$ indicate that the variable has good internal consistency. The full composite reliability value is presented in table 2 . 
Table 3. Composite Reliability Value

\begin{tabular}{ll}
\hline & Composite Reliability \\
\hline Intellectual Intelligence & 0,921 \\
Emotional Intelligence & 0,899 \\
Competence & 0,909 \\
Employees Performances & 0,942 \\
\hline Source: Output PLS $(2021)$ &
\end{tabular}

Source : Output PLS (2021)

Table 3 shows the composite reliability value of Intellectual Intelligence contract 0.821, Emotional Intelligence 0.899, Competence 0.909, and Employees Performances 0.942 . The four contracts composite reliability value $>0.70$ then is said to have good internal consistency.

The AVE value indicates the variance value of each indicator in the contract that can be captured by the variable more than the variance resulting from measurement errors. The EXPECTED AVE value > 0.5. The AVE value contracts Intellectual Intelligence 0.539, Emotional Intelligence 0.498 but close to 0.5, Competence 0.502, and Employees Performances 0.619. More results are presented in the table below.

Table 4. Average Variance Extracted Value (AVE)

\begin{tabular}{ll}
\hline & Average Variance Extracted (AVE) \\
\hline Intellectual Intelligence & 0,539 \\
Emotional Intelligence & 0,498 \\
Competence & 0,502 \\
Employees Performances & 0,619 \\
\hline
\end{tabular}

Source : Output PLS, (2021)

The reliability test is reinforced with Cronbach's alpha value. Cronbach's alpha reliability test limitation $>0.7$. Cronbach's alpha value obtained contracted intellectual intelligence contract 0.904, Emotional Intelligence 0.874, Competence 0.889, and Employees Performances 0.931. The results of the full Cronbach's alpha value are presented in table 5 .

Table 5. Cronbach's Alpha Value

\begin{tabular}{cc}
\hline & Cronbach's Alpha \\
\hline Intellectual Intelligence & 0,904 \\
Emotional Intelligence & 0,874 \\
Competence & 0,889 \\
Employees Performances & 0,931 \\
\hline
\end{tabular}

Source : Output PLS, (2021)

To test the structural model is done by looking at the value of R2, which is a Test of Goodness of the fit. Competence Contract obtained an R2 value of 0.491, which can be interpreted that the variant on Competence can be explained by the contract of Intellectual Intelligence and Emotional Intelligence of $49.1 \%$ while the remaining $50.9 \%(100 \%$ $49.1 \%$ ) described by other variables outside the research. Similarly, employees' 
performances contract with an R2 value obtained by 0.524 or $52.4 \%$. This value indicates that the contract variation of Employees Performances can be explained by the Contract of Intellectual Intelligence, Emotional Intelligence, and Competence of 52.4\%. The remaining $47.6 \%(100 \%-52.4 \%)$ described by other variables that were not studied. The results of the full R-square values are presented in table 6.

Table 6. R-Square Value

\begin{tabular}{cc}
\hline & R Square \\
\hline Competence & 0,491 \\
Performances & 0,524 \\
\hline
\end{tabular}

Source : Output PLS, (2021)

The next test is to look at the significance of independent contracts on dependents and answer what has been hypothesized. Testing with a significance level of 5\% if the t-statistic value $>1.96$, then the zero $(\mathrm{H} 0)$ hypothesis is rejected. The t-statistical value of the coefficient of influence of latent contracts is obtained from PLS Bootstrapping. Pls Bootstrapping Model results are presented in figure 4.

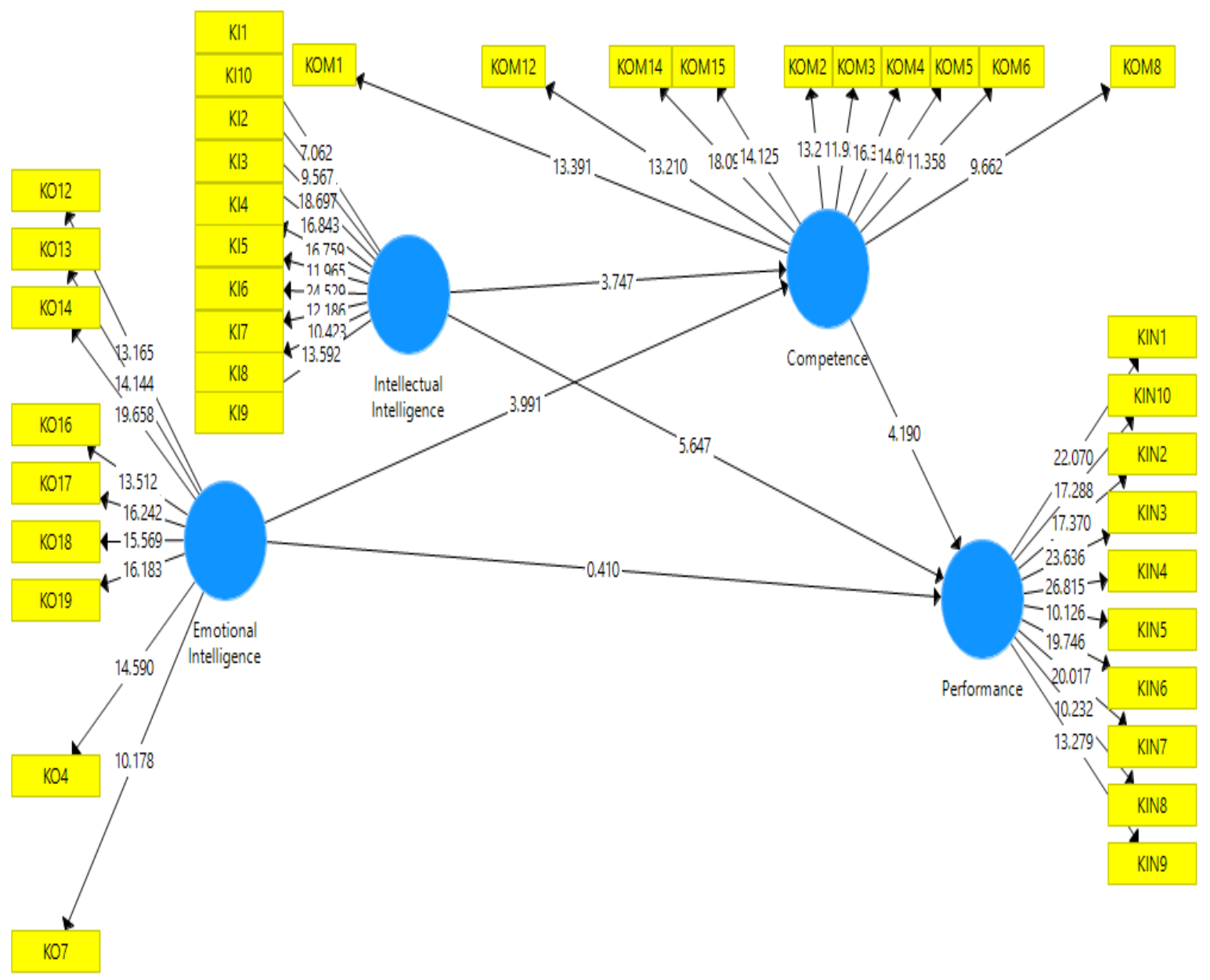

Figure 4. PLS Bootstraping Model 
These results equation can be explained as follows: the coefficient of the probability variable is 0.014 with a positive direction, which means that if there is an increase in probability, the earnings quality will increase by 0.014 . The size company variable coefficient is 1,157 with a positive direction, which means that if there is an increase in size company, the earnings quality will increase by 1,157 . The Investment Opportunity Set variable coefficient is 0,122 with a positive direction, which means that if there is an increase in Investment Opportunity Set, the earnings quality will increase by 0,122.

Table 7. Coefficient Values (Original Sample), Standard Error and T-Statistics

\begin{tabular}{|c|c|c|c|c|c|}
\hline & $\begin{array}{l}\text { Original } \\
\text { Sample (O) }\end{array}$ & $\begin{array}{l}\text { Sample Mean } \\
\text { (M) }\end{array}$ & $\begin{array}{l}\text { Stand up. Dev } \\
\text { (STDEV) }\end{array}$ & $\begin{array}{l}\text { T Statistics (| } \\
\text { O/STDEV|) }\end{array}$ & P Values \\
\hline Co $->$ Perf & 0,366 & 0,372 & 0,087 & 4,190 & 0,000 \\
\hline EI -> Co. & 0,383 & 0,380 & 0,096 & 3,991 & 0,000 \\
\hline EI $->$ Perf & 0,036 & 0,039 & 0,089 & 0,410 & 0,682 \\
\hline $\begin{array}{l}\text { Int I -> } \\
\text { Co. }\end{array}$ & 0,386 & 0,400 & 0,103 & 3,747 & $\mathbf{0 , 0 0 0}$ \\
\hline $\begin{array}{l}\text { Int I -> } \\
\text { Perf }\end{array}$ & 0,405 & 0,405 & 0,072 & 5,647 & 0,000 \\
\hline
\end{tabular}

Source : Output PLS, (2021)

H1 : The coefficient of intellectual intelligence's influence on Competence is 0.386, the standard error value is 0.103 and the t-statistical value is 3,747. Because the $t-$ statistical value of $3,747>1.96$ then receive H0. This proves that Intellectual Intelligence has a significant positive effect on Competence.

$\mathrm{H} 2$ : Coefficient of Emotional Intelligence influence on Competence of 0.383, standard error of 0.096 and $t$-statistical value of 3,991. Because the $t$-statistical value is 3,991 $>1.96$ then receive H0. This can be interpreted that Emotional Intelligence has a significant positive effect on Competence.

H3 : Competence's coefficient of influence on Employees Performances of 0.366, standard error 0.087 and t-statistical value of 4.190. Because the t-statistical value of 4,190 > 1.96 then receive H0. It can be stated that Competence significantly affects Employees Performances.

H4 : Intellectual Intelligence coefficient of influence on Employees Performances of 0.405, standard error 0.072 and t-statistical value of 5.647. Because the $t$-statistical value is $5,647<1.96$ then receive $\mathrm{H} 0$. It can be stated that Intellectual Intelligence significantly affects Employees Performances.

H5 : Coefficient of emotional intelligence influence on Employees Performances of 0.036, standard error 0.089 and t-statistical value of 0.410 . Because the $t$-statistical value of $0.410<1.96$ then reject H0. It can be stated that Emotional Intelligence has no significant effect on Employees Performances.

As for result indirect effect coefsien more presented in table 7: 
Table 8. Indirect Effect

\begin{tabular}{|c|c|c|c|c|c|}
\hline & $\begin{array}{l}\text { Original } \\
\text { Sample (O) }\end{array}$ & $\begin{array}{l}\text { Sample } \\
\text { Mean } \\
\text { (M) }\end{array}$ & $\begin{array}{l}\text { Stan Dev. } \\
\text { (STDEV) }\end{array}$ & $\begin{array}{l}\text { T Statistics (| } \\
\text { O/STDEV|) }\end{array}$ & P Values \\
\hline $\begin{array}{l}\text { Emotional Intelligence } \\
\text {-> Competence -> } \\
\text { Performance }\end{array}$ & 0,140 & 0,142 & 0,051 & 2,732 & $\mathbf{0 , 0 0 7}$ \\
\hline $\begin{array}{l}\text { Intellectual Intelligence } \\
\text {-> Competence -> } \\
\text { Performance }\end{array}$ & 0,141 & 0,148 & 0,051 & 2,740 & $\mathbf{0 , 0 0 6}$ \\
\hline
\end{tabular}

Table 8 shows that: (1)The effect of Intellectual Intelligence on Employees Performances through Competence is 0.141 , standard error 0.051, and t-statistical value is 2.740 . Because the t-statistical value of $2,740>1.96$ then receive H0. It can be stated that Intellectual Intelligence has a significant effect on Employees Performances through Competence. (2) The effect of Emotional Intelligence on employees' performance through Competence is 0.140 , the standard error is 0.051 , and the t-statistical value is 2.732 . Because the t-statistical value is 2,732>1.96 then receive H0. It can be stated that Emotional Intelligence has a significant effect on Employees Performances through competence.

\section{DISCUSSION}

Intellectual intelligence, competence, and performance. The results show that variables of intellectual information contribute in the expertise of employees in the Gorontalo provincial inspectorate. This means that the intelligence of Aperson has an important relation to his skill in carrying out the task. A highly skilled employee, such as knowledge, abilities, skills and attitudes in his position, is invited to work effectively, efficiently and productively. This is because with the relevant skills, the more able it is to perform its tasks. It can be concluded that the employees in the Gorontalo Inspectorate are already well-known in this case, and that their ability to manage or implement their intelligence becomes a factor that encourages performance and even affects their work. The institution can also be concerned to pay greater attention to the competence of other staff in improving and maximizing performance for the Gorontalo Provincial Inspectorate. The results of this study are also the same as the results of previous research conducted by (Rusnali, 2020) which states that Intellectual intelligence has a significant impact on competence and employee performance.

Emotional intelligence, competence and performance. First, emotional variables influence skill variables considerably. This is because respondents responded significantly to their emotional work management skills. Second, the results showed that emotional understanding can still not be seen as a variable that can influence employee performance, or even respondents judged that emotional intelligence is insufficient to achieve maximum results. These findings are certainly in line with the research results (Sierra et al., 2013). Emotional intelligence is seen from several sides: the level of education, gender, and age. The same technique was used in the study, namely the statistic Structural Equation Model (SEM), where the results showed that emotional intelligence has no significant effect on 
performance. Researchers see that the motivation in lecturers still does not affect their desire to work to get achievements. This may be a relationship between the university to the lecturers who are minimal in providing motivational encouragement to them to be given various awards or rewards to make the latest breakthroughs or work to the maximum.

Competence and performance. The results showed that competency has a positive and significant effect on the performance of employees. This means that the better the competence, the more performance will be improved in the Inspectorate of Gorontalo province. This is in line with research conducted (Meidita 2019), where a person's competence is still a benchmark related to their performance. Further, with regard to competence found indicators that need to be more optimized. In other words, low employee performance reflects the organization that wastes its resources, which in the end, the organization loses competitiveness that will reduce the scale of its business activities. Employee competence also affects the low performance of many organizations that will degrade the industry and the nation's economy, which tends to reduce the organization's success. Some beliefs can be considered to support the concept of new employee performance that concerns the production process as a complex system can be applied and applicable in society, environment, labor, capital, and organization. It is not essential from him but in a coordinated way into a unified unity. The success of employee performance in the organization also begins with the extent of its employees' quality of employee performance. To enforce the performance of employees organizasai to be better, it is necessary to uphold the competence of employees.

\section{CONCLUSION}

The summary results by applying Smart-PLS to the testing of hypotheses by the research model and by discussing the results lead to a conclusion: intellectual intelligence plays a significant role in the competence and performance of its employees. Simultaneously, the variable emotional intelligence does not influence employee performance significantly. But these variables influence skill variables significantly. That is due to the lack of positive reactions by respondents to emotional intelligence variables, some indicators being evaluated as low as one of the criteria of the performance. Emotional intelligence influences competence significantly. Indirect influence is tested. The results of this study are also consistent with research carried out (Rusnali, 2020) that has no significant performance effect on the emotional intelligence.

In the study, emotional intelligence was viewed from five levels based on (Goleman's, 2005). The emotional level of employees has no relation, or it can be said this variable is still considered foreign by the employees with their performance. The response from employees saw that emotional intelligence was only limited to what they felt when interacting and the workload given to them that affected their mood. Emotional management has not been able to be done by employees when the variable emotional intelligence is an essential element for maximizing work. Further research was conducted by (Pangestu and Efendi, 2019), where the results showed that intellectual intelligence and spiritual quotient have a significant influence on performance. At the same time, emotional intelligence is still not able to affect the performance of employees. This study also uses competency 
variables as mediation variables between intellectual intelligence, emotional intelligence, and spiritual intelligence to employee performance.

Based on the research that has been done, the author gives some suggestions including: first, can encourage and trigger the conduct of subsequent researches in the field of human resource management by using other variables that have not been included in this study, such as spiritual intelligence, work climate and work culture. Second, it is expected to increase the number of respondents and use the interview method to obtain valid data and describe the actual condition. This research is still simple in testing the relationship of related variables, namely intellectual intelligence and emotional intelligence, to employees' competence and performance.

\section{REFERENCES}

Adinda, K., dan Rohman, A. (2015). Pengaruh Kecerdasan Emosional dan Kecerdasan Intelektual terhadap Perilaku Etis Mahasiswa Akuntansi dalam Praktik Pelaporan Laporan Keuangan (Doctoral dissertation, Fakultas Ekonomika dan Bisnis).

Andreana, M. O.C., and amp; Princess, I. G. A.M. A. D. (2020). The effect of intellectual intelligence, emotional intelligence, spiritual intelligence and gender on ethical behavior. Accounting, 6(7), 1411-1418. https://doi.org/10.5267/j.ac.2020.8.008.

Anthony Chemero. (2003). An Outline of a Theory of Affordances. Ecological Psychology. Volume 15, 2003 - Issue 2. https://doi.org/10.1207/S15326969ECO1502 5.

Apriliani, D., and Rahadi, D. R. (2020). Learning Awards On Competency Development and Employee Performance In The Company. Journal of Business Management $(J M B), \quad 33(2), \quad 87-91 . \quad$ Retrieved from https://ejournal.stieibbi.ac.id/index.php/jmb/article/view/136.

Asri, J. L., and Imade, S. (2018). The Effect Of Intellectual Intelligence, Emotional Intelligence, Spiritual Intelligence And Types Of Accountant Professions At Ethical Attitudes Of Master Accounting Students. Russian Journal of Agricultural and SocioEconomic Sciences, 79(7).

Baldwin, J., Ioannidis, I., and Huegel, R. (2018). Culture, Ethics, and Communication. In Oxford Research Encyclopedia of Communication.https://doi.org/10.1093/acrefore/9780190228613.013.503 .

Bowen, S. A. (2018). Strategic Communication, Ethics of. The International Encyclopedia of Strategic Communication, 1-11. https://doi.org/10.1002/9781119010722.iesc0074.

Dewi, T. K., and Wirakusuma, M. G. (2018). The Influence of Intellectual Intelligence, Emotional Intelligence And Spiritual Intelligence On Ethical Behavior With Experience As a Moderating Variable. E-Journal of Economics and Business udayanaUniversity, 9,2089-2116.

Hacker, S. K., and Washington, M. (2017). Spiritual intelligence: going beyond IQ and EQ to develop resilient leaders. Global Business and Organizational Excellence, 36(3), 21-28. https://doi.org/10.1002/joe.21777.

Jöreskog, Karl G. (2004). Structural Equation Modeling with Ordinal Variables using LISREL. DOI:10.1214//nms/1215463803.

Juniari, N. K. E., Riana, I. G., and Amp; Subudi, M. (2015). The effect of motivation on work satisfaction and employee performance of government employees at STP Nusa 
Dua Bali. E-Journal of Economics and Business udayana University, 4(11), 823-840. Meidita, A. (2019). Effect of Training and Competency on Job Satisfaction Through Work Motivation. Maneggio: Master of Management Scientific Journal, 2(2), 226-237. https://doi.org/10.30596/maneggio.v2i2.3772.

Nguyen and Justin Hung Nguyen. (2020). Economic policy uncertainty and firm tax avoidance. Accounting and Finance. Volume 60, Issue 4. December 2020. https://doi.org/10.1111/acfi.12538.

Pangestu, E. S., and Efendi, R. (2019). The Intelligence Relations; Emotional, Intellectual, and Spiritual to Students' Ethical Attitudes. International Journal of Multicultural and MultireligiousUnderstanding, 6(6), 563-71.

Prihadi. (2004). Ludentifikasi, Pengukuran dan Pengembangan Kompetensi. Gramedia Pustaka Utama, Jakarta. ISBN: 979220850X.

Princess, I. G. A.M. A. D. (2020). Implementation of good government governance, intellectual intelligence, emotional, and spiritual intelligence in managerial performance of village government management. International Research Journal of Management, IT and Social Sciences, 7(1), 169-176. https://doi.org/10.21744/irjmis.v7n1.831.

Riasning, N. P., Datrini, L. K., dan Wianto, I. M. (2017). Pengaruh Kecerdasan Intelektual, Kecerdasan Emosional dan Kecerdasan Spiritual terhadap Sikap Etis Mahasiswa Akuntansi di Kota Denpasar. KRISNA: Kumpulan Riset Akuntansi, 9(1), 50-56. https://doi.org/10.22225/kr.9.1.328.50-56.

Robbins, S. (2007). Organizational Behavior (10th ed.). Jakarta: Publisher PT. Brilliant Jaya Tigers.

Roe. Robert. A. (2001). Trust Implications for Performance and Efectiveness. Europan Journal.

Rusnali, A. N. A. (2020). The Relationship between Spiritual Intelligence, Emotional Intelligence and Intellectual Intelligence with Communication Ethics of Students at IAIN Bone. 5(2), 173-83.

Said, A. N., dan Rahmawati, D. (2018). Pengaruh kecerdasan intelektual, kecerdasan emosional dan kecerdasan spiritual terhadap sikap etis mahasiswa akuntansi (studi empiris pada mahasiswa prodi akuntansi Universitas Negeri Yogyakarta). Nominal: Barometer Riset Akuntansi dan Manajemen, 7(1), 21-32. https://doi.org/10.21831/nominal.v7i1.19357

Sierra, M. de los D. V., del Rosal, M. Á.B., Romero, N. R., Villegas, K., and Lorenzo, M. (2013). Emotional intelligence and its relationship with gender, academic performance and intellectual abilities of undergraduates. Electronic Journal of Research in Educational Psychology, 11(2), 395-412.

Singh, A. P., and Dangmei, J. (2016). Understanding the Generation Z: The Future Workforce. South-Asian Journal of Multidisciplinary Studies, 3, 1-5.

Wardana, A., dan Mimba, N. (2016). Pengaruh Kecerdasan Intelektual, Kecerdasan Emosional, Kecerdasan Spiritual, Dan Gender Pada Sikap Etis Mahasiswa Magister. EJurnal Ekonomi Dan Bisnis, 10, 3501-3530.

Wiguna, I. P. I., and Yadnyana, K. (2019). The role of working experience moderates the effect of emotional intelligence, intellectual intelligence, and spiritual intelligence on the ethical decision of tax consultants in Bali area. International Research Journal of 
Management, IT and Social Sciences, 6(3), 18-28. https://doi.org/10.21744/irjmis.v6n3.624.

Yousapronpaiboon, K. (2014). SERVQUAL: Measuring higher education service quality in Thailand. Procedia-Social and Behavioral Sciences, 116, 1088-1095. https://doi.org/10.1016/j.sbspro.2014.01.350. 